\title{
Physicochemical Properties of Buffers Used in Simulated Biological Fluids with Potential Application for In Vitro Dissolution Testing: A Mini-review
}

John W. Mauger

e-mail: john.mauger@hsc.utah.edu

Department of Pharmaceutics and Pharmaceutical Chemistry, University of Utah College of Pharmacy, Salt Lake City, UT

\section{ABSTRACT}

This literature review focuses on the physicochemical properties of buffers used in biorelevant media for in vitro dissolution testing. Because biorelevant dissolution systems have been previously reviewed, this review is primarily related to the buffers used in biorelevant media and not the media, per se. It is based on a survey of the literature in areas including analytical chemistry; biochemistry; clinical, solution, and physical chemistry; dissolution science and technology; pharmaceutical sciences; simulated biological fluids; and buffer-related articles from the National Institute of Standards and Technology with the intent of identifying challenges in formulating buffered biorelevant dissolution media and also identifying general attributes that are useful in selecting a buffer for a particular dissolution application. Other topics include: (1) key physicochemical properties of buffers that affect experimental conditions and dissolution results; (2) buffer compatibility with a diverse array of ingredients found in biorelevant media; and (3) the potential to supplement the library of traditional buffers used for in vitro dissolution testing with zwitterionic buffers that were designed for biological application.

KEYWORDS: Buffers; physicochemical buffer properties; in vitro dissolution; biorelevant media; zwitterionic buffers.

\section{INTRODUCTION}

I he $\mathrm{pH}$ of buffered dissolution media is a singularly important parameter for dissolution testing because $\mathrm{pH}$ influences drug solubility and dissolution rate (1). Additionally, lack of $\mathrm{pH}$ control negatively influences the reproducibility of the results (2). The history of dissolution media over the past 20 years has been the subject of a recent review (2), which concluded that "dissolution testing has been and will continue to be the paradigm in which the ability of the product to release the drug under physiologically relevant conditions is increasingly emphasized." Marques et al. (3) support this conclusion in their review of simulated biological fluids that have application for in vitro dissolution testing.

Buffers have maintained a central role in the evolution of dissolution media. Standardized buffers, exemplified by those in the USP (4), are commonly used as in vitro dissolution media. These buffers are chemically defined, cover a useful $\mathrm{pH}$ range, and have known ionic strength and buffer capacity. The bicarbonate buffer system has been studied as a physiologically relevant medium (5), and a recent development in the evolution of biorelevant dissolution media is the use of diluted phosphate buffers as a surrogate for the bicarbonate buffer $(5,6)$.
Developing buffered systems that simulate biological fluids is an active area of research in several biomedical areas $(7,8)$. These buffers share many of the challenges encountered with buffers used for in vitro dissolution testing including requirements for ionic strength, buffer capacity, pH control, biological relevancy, and avoidance of incompatibilities. These simulated biological fluids exhibit the following general characteristics: (1) the buffer capacity reflects the function at a biological site, such as the eye; (2) even at relatively low concentrations, the buffer contributes significantly to the physicochemical properties of the simulated biological fluid; and (3) sodium chloride and other salts contribute substantially to the ionic strength of the simulated biological fluid.

Although aqueous buffers alone cannot be expected to fulfill all the requirements of biorelevant media, buffers will likely continue to play a central role in controlling the $\mathrm{pH}$ of complex formulations simulating biological fluids (3, 9). The use of biorelevant dissolution media to forecast in vivo drug performance has been reviewed (9). This minireview focuses on the physicochemical factors related to buffers used in these media and not the biorelevant dissolution media, per se. This mini-review is based on a survey of the literature associated with buffers in general 
and, specifically, biologically relevant buffers, with the intent of identifying challenges in formulating buffered dissolution media and identifying general attributes that are useful in selecting a buffer for a particular application.

\section{Challenges Associated with Formulating Buffered Biorelevant Dissolution Media}

Recent developments in buffered dissolution media point to several challenges due, in part, to having significantly reduced buffer capacity in comparison with traditional buffered dissolution media. For example, the currently used USP phosphate buffer, $\mathrm{pH} 6.8$, has a total phosphate concentration of $50 \mathrm{mM}$ and a buffer capacity of $29 \mathrm{mM} /$ $\Delta \mathrm{pH}$ (6). By comparison, the average concentration of the bicarbonate buffer system in the small intestine is 6-20 $\mathrm{mM}$, which corresponds to a buffer capacity of 2.48-13 $\mathrm{mM} / \Delta \mathrm{pH}$ (6). Krieg et al. (6) note that external control of $\mathrm{pH}$ may be necessary to maintain the $\mathrm{pH}$ of the bulk solution due to the low buffering capacity of surrogate phosphate buffers. Therefore, maintaining a stable $\mathrm{pH}$ with a buffer having relatively low buffer capacity is one challenge for a biorelevant dissolution medium that simulates in vivo conditions. Other challenges and factors affecting buffer performance include the potential for incompatibilities between the buffer and other ingredients in a complex biorelevant dissolution media formulation $(3,9)$; the effect of ionic strength contributed by the buffer on enzymes and bovine serum albumin (10-12); and an interaction between the buffer, metals, and polyvalent cations (13-15).

These challenges draw attention to the need to identify general physicochemical characteristics and attributes that are useful for selecting a buffer for a specific biorelevant dissolution medium.

\section{Identifying General Characteristics Useful for Selecting Buffers for Biorelevant Dissolution Media}

Good et al. $(16,17)$ discussed characteristics and attributes for buffers used in biological and biochemical research that have proved to be useful in selecting a buffer for a specific application. Good's original list can be modified to describe general buffer characteristics and attributes applicable to biorelevant media used for in vitro dissolution testing. These include: (1) buffer pKa within $\pm 1 \mathrm{pH}$ unit of the target $\mathrm{pH}$, (2) sufficient buffer capacity to maintain $\mathrm{pH}$ control, (3) minimal buffer-related ionic strength effects and minimal buffer-pKa dependence on temperature and ionic strength, (4) compatibility with other dissolution media components, (5) low absorbance spectra in UV and visible regions, (6) buffer effect on drug solubility, (7) nonreactivity with atmospheric gases, and compliance with standards (8) for safety and toxicity.
A brief outline of buffer definitions and terminology will be provided as a preface to a review of these characteristics.

\section{Buffer Definitions and Terminology}

For buffers with a single ionization or well-separated pKa values, the following definitions and terminology, according to Ellis et al. (18), follow for the dissociation of a weak acid, $\mathrm{HA}^{\mathrm{z}+1}$ :

$$
H A^{z+1} \leftrightarrow \mathrm{H}^{+}+\mathrm{A}^{\mathrm{z}}
$$

where $z$ is the charge on the conjugate base, $A^{z}$. The thermodynamic dissociation constant, $\mathrm{Ka}$, is given by:

$$
\mathrm{Ka}=\left(\mathrm{a}_{\mathrm{H}}{ }^{+} \mathrm{a}_{\mathrm{A}}{ }^{\mathrm{z}}\right) /\left(\mathrm{a}_{\mathrm{HA}}{ }^{\mathrm{z}+1}\right) ; \mathrm{a}_{\mathrm{i}}=\left[\mathrm{c}_{\mathrm{i}}\right] \mathrm{pi}
$$

where the activity of each ion, $a_{i}$, is the product of its molar or molal concentration $\left[\mathrm{c}_{\mathrm{i}}\right]$ and activity coefficient, $\gamma_{i}$. Equation 1 can now be expressed in terms of molar or molal concentrations, denoted by square brackets [ ], with each concentration term being multiplied by its respective activity coefficient, $\gamma_{\mathrm{i}}$ :

$$
\mathrm{Ka}=\left(\gamma_{\mathrm{H}^{+}}{ }\left[\mathrm{H}^{+}\right] \gamma_{\mathrm{A}}{ }^{\mathrm{z}}\left[\mathrm{A}^{\mathrm{z}}\right]\right) /\left(\gamma_{\mathrm{HA}}{ }^{\mathrm{z}+1}\left[\mathrm{HA}^{\mathrm{z}+1}\right]\right)
$$

A commonly used definition of the apparent dissociation constant, Ka', is given by the following expression (18):

$$
\mathrm{Ka}^{\prime}=\left(\mathrm{YH}^{+}\left[\mathrm{H}^{+}\right]\left[\mathrm{A}^{\mathrm{z}}\right]\right) /\left[\mathrm{H} \mathrm{A}^{\mathrm{z}+1}\right]
$$

and the logarithmic form of Equation 4 is:

$$
\mathrm{pH}=-\log \left(\mathrm{\gamma H}_{\mathrm{H}^{+}}\left[\mathrm{H}^{+}\right]\right)=\mathrm{pKa}+\log \left[\mathrm{A}^{z}\right] /\left[\mathrm{HA}^{\mathrm{z}+1}\right]
$$

Examples of common buffer systems that follow the general form of Equation 5 are:

$$
\begin{aligned}
& \text { acetic acid: } \mathrm{CH}_{3} \mathrm{CO}_{2} \mathrm{H} \leftrightarrow \mathrm{H}^{+}+\mathrm{CH}_{3} \mathrm{CO}_{2}^{-}, \mathrm{z}=-1, \mathrm{z}+1=0 \\
& \mathrm{pH}=\mathrm{pKa}+\log \left(\left[\mathrm{CH}_{3} \mathrm{CO}_{2}^{-}\right] /\left[\mathrm{CH}_{3} \mathrm{CO}_{2} \mathrm{H}\right]\right) \\
& \mathrm{R}-\mathrm{NH}_{3}{ }^{+} \leftrightarrow \mathrm{H}^{+}+\mathrm{R}-\mathrm{NH}_{2}, \mathrm{z}=0, \mathrm{z}+1=+1 \\
& \mathrm{pH}=\mathrm{pKa}+\log \left(\left[\mathrm{R}-\mathrm{NH}_{2}\right] /\left[\mathrm{R}-\mathrm{NH}_{3}{ }^{+}\right]\right) \\
& \mathrm{pH}=\mathrm{pKa}_{2}{ }^{1}+\log \left(\left[\mathrm{HPO}_{4}{ }^{-2}\right] /\left[\mathrm{H}_{2} \mathrm{PO}_{4}{ }^{-1}\right]\right) \\
& \mathrm{pH}=\mathrm{pKa}_{2}{ }^{\prime}+\log \left(\left[\mathrm{NH}_{2} \mathrm{CH}_{2} \mathrm{CO}_{2}{ }^{-}\right] /\left[\mathrm{NH}_{3}{ }^{+} \mathrm{CH}_{2} \mathrm{CO}_{2}{ }^{-}\right]\right) \text {. }
\end{aligned}
$$

Equation 5 can be expressed in a more general form as:

$$
\mathrm{pH}=\mathrm{pKa}+\log ([\text { conjugate base }] /[\text { weak acid }])
$$


Equating [conjugate base] and [weak acid] with their analytical concentrations, $\mathrm{C}_{\mathrm{cb}}$, and $\mathrm{C}_{\mathrm{wa}}$, respectively, and substituting into Equation 6 yields:

$$
\mathrm{pH}=\mathrm{pKa}+\log \left(\mathrm{C}_{\mathrm{cb}} / \mathrm{C}_{\mathrm{wa}}\right)
$$

Equation 7, commonly referred to as the buffer equation, is valid in the $\mathrm{pH}$ range of 3-11 where the concentration of the hydronium and hydroxyl ions is much less than the concentration of the buffer species. A complete derivation of the buffer equation, with assumptions and constraints related to its use, is provided by Butler (19).

The ionic strength, I, for the buffer systems described by Equation 1 is expressed by (18):

$$
\left.I=\left[H A^{z+1}\right]\left\{\left((z+1)^{2}+|z+1|\right) / 2\right)\right\}+\left[A^{z}\right]\left\{\left(z^{2}+|z|\right) / 2\right\}
$$

The factors in curly brackets \{\} associated with $\left[\mathrm{HA}^{z+1}\right]$ and $\left[A^{z}\right]$ as a function of $z$, and as constructed by Ellis et al. (18), are useful to calculate I and are found in Table 1.

Table 1. The Factors in \{ \} Associated with $\left[H A^{z+1}\right]$ and $\left[A^{z}\right]$ as a Function of $z$, and as Constructed by Ellis et al ${ }^{a}$

\begin{tabular}{|c|c|c|}
\hline & \multicolumn{2}{|l|}{ Factor \{ \}associated with } \\
\hline$z$ & $\mathrm{HA}^{\mathrm{z}+1}$ & $\mathrm{~A}^{z}$ \\
\hline 2 & 6 & 3 \\
\hline 1 & 3 & 1 \\
\hline 0 & 1 & 0 \\
\hline-1 & 0 & 1 \\
\hline-2 & 1 & 3 \\
\hline
\end{tabular}

aEllis, K. J.; Morrison, J.F. Buffers of Constant lonic Strength for Studying pH-Dependent Processes. Methods Enzymol. 1982, 87, 405-426. DOI: 10.1016/S0076-6879(82)87025-0 (18).

\section{Discussion of Characteristics Potentially Useful in Selecting Buffers for Biorelevant Dissolution Media Relationship Between the Target Dissolution Media pH And Buffer $p K a$}

For a buffer to have sufficient buffer capacity to be effective, its $\mathrm{pH}$ must be within a range of $\mathrm{pKa}_{\text {buffer }} \pm 1$ or preferably within pKa buffer $\pm 0.5(20)$. Using a criterion of pKa buffer \pm 0.5 assures that the effectiveness of the buffer will not be less than $73 \%$ of the maximum buffer capacity for a specified buffer concentration. Thermodynamic pKa data $(I=0)$ are available for buffers commonly used in biorelevant dissolution media (see Table 2) (21-32); however, these values do not reflect the electrolyte environment where buffer concentration is relatively low and salts, such as sodium chloride, contribute significantly to the ionic strength of the media. For example, the thermodynamic $\mathrm{pKa}_{2}$ for a phosphate buffer system at $37{ }^{\circ} \mathrm{C}$ is 7.181 (Table 2) (21-32) while $\mathrm{pKa}_{2}$ ' is 6.75 at $37^{\circ} \mathrm{C}$ under conditions where the buffer concentration is low and sodium chloride contributes significantly to the ionic strength of the buffer solution (33). Selecting a pKa' value measured at a temperature close to test conditions is another factor because pKa-temperature dependence for buffers such as TRIS may be significant (34).

The $\mathrm{pH}$ required for simulated biological fluids ranges from 1.6 for fasting simulated gastric fluid to 7.7 for simulated semen $(3,9)$. The $\mathrm{pH}$ of the distal colon of fed healthy adults is reported to be approximately 8.1 (35).

Table 3 provides $\mathrm{pKa}^{\mathrm{a}}$ data for buffers relative to this target $\mathrm{pH}$ range $(3,9,16,17,25,34,36-47)$. The buffers listed first are those included in the formulations for the simulated biological fluids provided in Marques et al (3) and Klein (9). Buffers listed second under "Buffers for Biological Research" heading are those described by Good et al. $(16,17)$ that were developed with specific biocompatibility criteria in mind and are potentially useful for buffered dissolution media for liposomal drug formulations as described by Xu et al. (48).

The pKa' values in Table 3 differ significantly from the thermodynamic pKa values in Table 2, suggesting that thermodynamic values are potentially less useful in selecting a buffer to meet the target $\mathrm{pH}$ for biorelevant dissolution media. The data in Table 3 also show that buffers currently used in simulated biological fluids adequately cover the $\mathrm{pH}$ range from 1.2 to 8.4 while the zwitterionic buffers developed for biological research supplement the current buffer library in the $\mathrm{pH}$ range of 5.5-8.3. The zwitterionic buffer 2-( $N$-morpholino) ethanesulfonic acid (MES) is currently being used for in vitro dissolution testing of liposomes (48). Not all pKa' data in Table 3 were measured in either biologically relevant media or at temperatures related to dissolution test conditions. In the case of lactic and citric acids, stoichiometric or concentration-based pKa data (which differ from the definition given by Equation 5) were only available at $25^{\circ} \mathrm{C}$. A pKa ${ }_{2}^{\prime}$ value for maleic acid was estimated using data from Marques et al. (3) for fed state simulated intestinal fluid (FeSSIF) middle, pH 5.8, where no temperature is stated.

The literature search for pKa' values for buffers used in biorelevant dissolution media resulted in locating a database of $\mathrm{pH}$ values measured at $37^{\circ} \mathrm{C}$ under conditions where the ratio of conjugate base to weak acid is defined (e.g., 1:1); the total concentration of the buffer is known; and the total ionic strength is fixed and held constant by 
Table 2. Thermodynamic pKa Values, Charge on Conjugate Base and Weak Acid, Ionization Enthalpies, and pKa-Temperature Differential for Buffers Listed in Table 1

\begin{tabular}{|c|c|c|c|c|c|}
\hline Buffer & \multicolumn{2}{|c|}{$\begin{array}{l}\text { Thermodynamic } \\
\text { pKa }(I=0)\end{array}$} & $\begin{array}{l}\text { Charge on conjugate } \\
\text { base }(z) \text { and weak acid } \\
(z+1)\end{array}$ & $\begin{array}{c}\text { Ionization Enthalpy, } \\
\Delta \mathrm{H}^{\circ}, \mathrm{kJ} / \mathrm{mole} \\
\text { at } 298.15^{\circ} \mathrm{C}\end{array}$ & $\begin{array}{c}\mathrm{dpKa} / \mathrm{dT}^{\mathrm{T}}=-\Delta \mathrm{H}^{\circ} / \\
\left(2.303 \mathrm{RT}^{2}\right) ; \\
\mathrm{T}=298.15 \mathrm{~K} \\
\mathrm{R}=8.314472 \mathrm{~J} \mathrm{~K}^{-1} \mathrm{~mol}^{-1}\end{array}$ \\
\hline \multicolumn{6}{|l|}{ Lactate $^{a}$} \\
\hline $\begin{array}{c}\mathrm{CH}_{3} \mathrm{CHOHCO}_{2} \mathrm{H} \leftrightarrow \mathrm{H}^{+} \\
\quad+\mathrm{CH}_{3} \mathrm{CHOHCO}_{2}^{-}\end{array}$ & $3.862\left(25^{\circ} \mathrm{C}\right)$ & $3.872\left(37.5^{\circ} \mathrm{C}\right)$ & $-1,0$ & $-0.251^{a}$ & $+1.48 \mathrm{E}-04$ \\
\hline \multicolumn{6}{|l|}{ Citrate $^{b}$} \\
\hline $\mathrm{H}_{3} \mathrm{~L} \leftrightarrow \mathrm{H}^{+}+\mathrm{H}_{2} \mathrm{~L}^{-}$ & $3.128\left(25^{\circ} \mathrm{C}\right)$ & $3.105\left(37^{\circ} \mathrm{C}\right)$ & $-1,0$ & $+4.170^{b}$ & $-2.45 \mathrm{E}-03$ \\
\hline $\mathrm{H}_{2} \mathrm{~L}^{-} \leftrightarrow \mathrm{H}^{+}+\mathrm{HL}^{-2}$ & $4.761\left(25^{\circ} \mathrm{C}\right)$ & $4.750\left(37^{\circ} \mathrm{C}\right)$ & $-2,-1$ & $+2.437^{b}$ & $-1.43 \mathrm{E}-03$ \\
\hline $\mathrm{HL}^{-2} \leftrightarrow \mathrm{H}^{+}+\mathrm{L}^{-3}$ & $6.396\left(25^{\circ} \mathrm{C}\right)$ & $6.429\left(37^{\circ} \mathrm{C}\right)$ & $-3,-2$ & $-3.359^{b}$ & $+1.97 \mathrm{E}-03$ \\
\hline \multicolumn{6}{|l|}{$\mathrm{H}_{3} \mathrm{~L}=\mathrm{C}_{6} \mathrm{H}_{8} \mathrm{O}_{7}$} \\
\hline \multicolumn{6}{|l|}{ Acetate $^{c}$} \\
\hline $\begin{array}{c}\mathrm{CH}_{3} \mathrm{CO}_{2} \mathrm{H} \leftrightarrow \mathrm{H}^{+}+ \\
\mathrm{CH}_{3} \mathrm{CO}_{2}^{-}\end{array}$ & $4.756\left(25^{\circ} \mathrm{C}\right)$ & $4.766\left(37^{\circ} \mathrm{C}\right)$ & $-1,0$ & $-0.469^{c}$ & $+2.76 \mathrm{E}-04$ \\
\hline \multicolumn{6}{|l|}{ Carbonate $^{d}$} \\
\hline $\mathrm{H}_{2} \mathrm{CO}_{3} \leftrightarrow \mathrm{H}^{+}+\mathrm{HCO}_{3}^{-}$ & $6.3514\left(25^{\circ} \mathrm{C}\right)$ & $6.303\left(37^{\circ} \mathrm{C}\right)$ & $-1,0$ & $+9.15^{k}$ & $-5.38 \mathrm{E}-03$ \\
\hline \multicolumn{6}{|l|}{ Maleate $^{e}$} \\
\hline $\mathrm{H}_{2} \mathrm{~L} \leftrightarrow \mathrm{H}^{+}+\mathrm{HL}^{-1}$ & $1.932\left(25^{\circ} \mathrm{C}\right)$ & $1.892\left(37^{\circ} \mathrm{C}\right)$ & $-1,0$ & $+5.462^{e}$ & $-3.21 \mathrm{E}-03$ \\
\hline $\mathrm{HL}^{-1} \leftrightarrow \mathrm{H}^{+}+\mathrm{L}^{-2}$ & $6.139\left(25^{\circ} \mathrm{C}\right)$ & $6.166\left(37^{\circ} \mathrm{C}\right)$ & $-2,-1$ & $-3.736^{e}$ & $+2.20 \mathrm{E}-03$ \\
\hline \multicolumn{6}{|l|}{$\mathrm{H}_{2} \mathrm{~L}=\mathrm{C}_{4} \mathrm{H}_{4} \mathrm{O}_{4}$} \\
\hline \multicolumn{6}{|l|}{ Phosphate ${ }^{f}$} \\
\hline $\mathrm{H}^{2} \mathrm{PO}_{4}^{-1} \leftrightarrow \mathrm{H}^{+}+\mathrm{HPO}_{4}^{-2}$ & $7.198\left(25^{\circ} \mathrm{C}\right)$ & $7.181\left(37^{\circ} \mathrm{C}\right)$ & $-2,-1$ & $+4.10^{f}$ & $-2.41 \mathrm{E}-03$ \\
\hline \multicolumn{6}{|l|}{ TRIS $^{g}$} \\
\hline $\mathrm{HL}^{+} \leftrightarrow \mathrm{H}^{+}+\mathrm{L}$ & $8.075\left(25^{\circ} \mathrm{C}\right)$ & $7.752\left(37^{\circ} \mathrm{C}\right)$ & 0,1 & $+47.5^{k}$ & $-2.79 \mathrm{E}-02$ \\
\hline \multicolumn{6}{|l|}{$\mathrm{L}=\mathrm{C}_{4} \mathrm{H}_{11} \mathrm{NO}_{3}$} \\
\hline \multicolumn{6}{|l|}{$\mathrm{MES}^{h}$} \\
\hline $\mathrm{HL}^{ \pm} \leftrightarrow \mathrm{H}^{+}+\mathrm{L}^{-}$ & $6.270\left(25^{\circ} \mathrm{C}\right)$ & $6.170\left(37^{\circ} \mathrm{C}\right)$ & $-1,0$ & $+14.8^{k}$ & $-8.70 \mathrm{E}-03$ \\
\hline \multicolumn{6}{|l|}{$\mathrm{HL}=\mathrm{C}_{6} \mathrm{H}_{13} \mathrm{NO}_{4} \mathrm{~S}$} \\
\hline \multicolumn{6}{|l|}{ MOPS $^{i}$} \\
\hline $\mathrm{HL}^{ \pm} \leftrightarrow \mathrm{H}^{+}+\mathrm{L}^{-}$ & $7.184\left(25^{\circ} \mathrm{C}\right)$ & $7.041\left(37^{\circ} \mathrm{C}\right)$ & $-1,0$ & $+21.1^{k}$ & $-1.24 \mathrm{E}-02$ \\
\hline \multicolumn{6}{|l|}{$\mathrm{HL}=\mathrm{C}_{7} \mathrm{H}_{15} \mathrm{NO}_{4} \mathrm{~S}$} \\
\hline \multicolumn{6}{|l|}{ HEPES ${ }^{h}$} \\
\hline $\mathrm{HL}^{ \pm} \leftrightarrow \mathrm{H}^{+}+\mathrm{L}^{-}$ & $7.565\left(25^{\circ} \mathrm{C}\right)$ & $7.427\left(37^{\circ} \mathrm{C}\right)$ & $-1,0$ & $+20.4^{k}$ & $-1.20 \mathrm{E}-02$ \\
\hline \multicolumn{6}{|l|}{$\mathrm{HL}=\mathrm{C}_{8} \mathrm{H}_{18} \mathrm{~N}_{2} \mathrm{O}_{4} \mathrm{~S}$} \\
\hline \multicolumn{6}{|l|}{ HEPPS } \\
\hline $\mathrm{HL}^{ \pm} \leftrightarrow \mathrm{H}^{+}+\mathrm{L}^{-}$ & $7.957\left(25^{\circ} \mathrm{C}\right)$ & $7.810\left(37^{\circ} \mathrm{C}\right)$ & $-1,0$ & $+21.3^{k}$ & $-1.25 \mathrm{E}-02$ \\
\hline $\mathrm{HL}=\mathrm{C}_{6} \mathrm{H}_{2} \mathrm{ON}_{2} \mathrm{O}_{4} \mathrm{~S}$ & & & & & \\
\hline
\end{tabular}

${ }^{a}$ Nims, L. F.; Smith, P. K. The Ionization of Lactic Acid from Zero to Fifty Degrees. J. Biol. Chem. 1936, 113, 145-152 (22).

${ }^{b}$ Bates, R. G.; Pinching, G. D. Resolution of the Dissociation Constants of Citric Acid at 0 to $50^{\circ}$, and Determination of Certain Related Thermodynamic Functions. J. Am. Chem. Soc. 1949, 71, 1274-1283. DOI: 10.1021/ja0117a039 (23).

"Harned, H. S.; Ehlers, R. W. The Dissociation of Acetic Acid from 0 to $60^{\circ}$ Centigrade. J. Am. Chem. Soc. 1933, 55 (2), 652-656. DOI: 10.10.21/ja01329a027 (24)

${ }^{d}$ Harned, H. S.; Bonner, F. T. The First Ionization Constant of Carbonic Acid in Aqueous Solutions of Sodium Chloride. J. Am. Chem. Soc., 1945, 67 (6), 1026-1031. DOI: 10.1021/ ja01222a037 (25)

'Das, R. C. Thermodynamics of DL-Malic, Maleic and Fumaric Acids in Water and Water + Dioxan Mixtures. J.C.S. Faraday I. 1980, 76, 2152-2158 (26).

${ }^{\prime}$ Bates, R. G.; Acree, S. F. pH of Aqueous Mixtures of Potassium Dihydrogen Phosphate and Disodium Hydrogen Phosphate at $0^{\circ}$ to $60{ }^{\circ} \mathrm{C}$. J. Res. Natl. Bur. Std. (U.S.) 1945, 34, 373-394 (28)

${ }^{9}$ Bates, R. G.; Hetzer, H. G. Dissociation Constant of the Protonated Acid Form of 2-Amino-2-(Hydroxymethyl)-1,3-Propanediol [TRIS-Hydroxymethyl)-Aminomethane] and Related Thermodynamic Quantities from 0 to $50^{\circ} \mathrm{C}$. J. Phys. Chem. 1961, 65 (4), 667-671. DOI: 10.1021/j100822a017 (27).

${ }^{h}$ Vega, C. A.; Bates, R. G. Buffers for the Physiological pH Range: Thermodynamic Constants of Four Substituted Aminoethanesulfonic Acids from 5 to $50{ }^{\circ} \mathrm{C}$. Anal. Chem. 1976, 48 (9), 1293-1296. DOI: 10.1021/ac50003a010 (29).

'Sankar, M.; Bates, R. G. Buffers for the Physiological pH Range: Thermodynamic Constants of 3-(N-Morpholino)propanesulfonic Acid from 5 to $50{ }^{\circ} \mathrm{C}$. Anal. Chem. 1978, 50 (13), $1922-1924(30)$

jRoy, R. N.; Moore, C. P.; Lord, P.; Mrad, D.; Roy, L. N.; Good, W. S.; Niederschmidt, J.; Kuhler, K. M. Thermodynamic Constants of N-(2-hydroxyethyl) piperazine-N'-3-

propanesulfonic acid (HEPPS) and (3-[N-morpholinol])-2-hydroxypropanesulfonic acid (MOPSO) from Temperatures $278.15 \mathrm{~K}$ to $328.15 \mathrm{~K}$. J. Chem. Thermodyn. 1997, 29,

$1323-1331(31)$

${ }^{k}$ Ionization enthalpy values taken from Goldberg, R. N.; Kishore, N.; Lennen, R. M. Thermodynamic Quantities for the Ionization Reactions of Buffers. J. Phys. Chem. Ref. Data. 2002, 31 (2), 231-370. DOI: 10.1063/1.1416902 (21).

'dpKa/dT values were calculated using the van't Hoff Equation as described in Roig, T.; Bäckman, P.; Olofsson, G. Ionization Enthalpies of Some

Common Zwitterionic Hydrogen-Ion Buffers for Biological Research. Acta Chemica Scandinavica, 1993, 47, 899-901 (32).

Abbreviations: HEPES, N-2-hydroxyethylpiperazine-N'-ethanesulfonic acid; HEPPS, N-2-hydroxyethylpiperazine-N'-propanesulfonic acid; MES, 2-(N-morpholino)ethanesulfonic acid; MOPS, 3-(N-morpholino)propanesulfonic acid; TRIS, tris-(hydroxymethyl) aminomethane. 


\section{Table 3. Buffer pKa' Values for Buffers Currently Use in Simulated Biological Fluid Formulas ${ }^{a, b}$ or for Biological Research ${ }^{c, d}$}

\begin{tabular}{|c|c|c|c|}
\hline \multicolumn{4}{|c|}{ Buffers Currently Used in Simulated Biological Fluid Formulas ${ }^{a, b}$} \\
\hline Buffer System & рКа' & $\begin{array}{l}\text { Buffer Range Based on } \\
\text { pH }=\mathrm{pKa} \pm 0.5\end{array}$ & Comments \\
\hline $\mathrm{HCL} / \mathrm{KCL}$ & & $\begin{array}{c}1.2-2.2 \text { (based on USPHCL/ } \\
\text { KCLBuffer) }\end{array}$ & $\begin{array}{l}\text { Bower \& Bates' provide } \\
\text { compositions and buffer values for } \\
\text { solutions of pH } 1.0 \text { to } 2.2\end{array}$ \\
\hline Lactic Acide $^{e}$ & 3.63 & 3.1-4.1 & $\begin{array}{c}\text { pKa' (based on hydrogen ion } \\
\text { concentration) }{ }^{m} \text { at I }=0.15 \text { (molal } \\
\text { scale) } \mathrm{NaCl}, 25^{\circ} \mathrm{C}\end{array}$ \\
\hline \multirow{3}{*}{ Citric Acid ${ }^{f}$} & $\mathrm{pKa}_{1}{ }^{\prime}=2.87$ & 2.4-3.4 & \multirow{3}{*}{$\begin{array}{c}\text { pKa' (based on hydrogen ion } \\
\text { concentration) }{ }^{m} \text { at I }=0.15 \\
\text { (concentration scale not given) } \\
\mathrm{NaCl}, 25^{\circ} \mathrm{C}\end{array}$} \\
\hline & $\mathrm{pKa}_{2}{ }^{\prime}=4.28$ & $3.8-4.8$ & \\
\hline & $\mathrm{pKa}_{3}{ }^{\prime}=5.58$ & $5.1-6.1$ & \\
\hline Acetic Acid ${ }^{g}$ & 4.62 & 4.1-5.1 & $\begin{array}{l}\text { pKa' measured at } \mathrm{I}=0.1 \\
\text { (molar scale) } \mathrm{KCL}, 35^{\circ} \mathrm{C}\end{array}$ \\
\hline Carbonate $^{h}$ & $\mathrm{pKa}_{1}{ }^{\prime}=6.07$ & $5.6-6.6$ & $\begin{array}{c}\text { pKa' at I }=0.1 \\
\text { (molal scale) } \\
\mathrm{NaCl}, 35^{\circ} \mathrm{C}\end{array}$ \\
\hline Maleic Acid ${ }^{i}$ & $\mathrm{pKa}_{2}{ }^{\prime}=5.83$ & $5.3-6.3$ & $\mathrm{pKa}_{2}{ }^{\prime}$ estimated ${ }^{i}$ \\
\hline Phosphate $^{g}$ & $\mathrm{pKa}_{2}{ }^{\prime}=6.78$ & $6.3-7.3$ & $\begin{array}{l}\text { pKa' measured at } \mathrm{I}=0.1 \\
\text { (molar scale) } \mathrm{KCL}, 35^{\circ} \mathrm{C}\end{array}$ \\
\hline Tris/TRIS-HCL & 7.91 & 7.4-8.4 & $\begin{array}{l}\text { pKa' estimated from pH data for } \\
\text { a buffer composed of } 0.05 \text { molal } \\
\text { TRIS, } 0.05 \text { molal TRIS- } \mathrm{HCL} \text { and made } \\
\text { isotonic with } \mathrm{NaCl} \text { at } 37^{\circ} \mathrm{C}\end{array}$ \\
\hline \multicolumn{4}{|c|}{ Buffers for Biological Research ${ }^{c, d}$} \\
\hline $\mathrm{MES}^{g, k}$ & pKa2' $=5.98$ & $5.5-6.5$ & $\begin{array}{l}\text { pKa' measured at I }=0.1 \\
\text { (molar scale) } \mathrm{KCL}, 35^{\circ} \mathrm{C}\end{array}$ \\
\hline MOPS $^{g, k}$ & $\mathrm{pKa}_{2}{ }^{\prime}=6.96$ & $6.5-7.5$ & $\begin{array}{l}\text { pKa' measured at } \mathrm{I}=0.1 \\
\text { (molar scale) } \mathrm{KCL}, 35^{\circ} \mathrm{C}\end{array}$ \\
\hline HEPES $g, k$ & $\mathrm{pKa}_{2}{ }^{\prime}=7.33$ & $6.8-7.8$ & $\begin{array}{l}\text { pKa' measured at I }=0.1 \\
\text { (molar scale) } \mathrm{KCL}, 35^{\circ} \mathrm{C}\end{array}$ \\
\hline HEPPS $^{g, k}$ & $\mathrm{pKa}_{2}{ }^{\prime}=7.75$ & $7.3-8.3$ & $\begin{array}{l}\text { pKa' measured at I }=0.1 \\
\text { (molar scale) } \mathrm{KCL}, 35^{\circ} \mathrm{C}\end{array}$ \\
\hline
\end{tabular}

aMarques, M. R. C.; Loebenberg, R.; Almukainzi, M. Simulated Biological Fluids with Possible Application in Dissolution Testing. Dissolution Technol. 2011, 18 (3), 15-28. DOI: 10.14227/DT180311P15 (3).

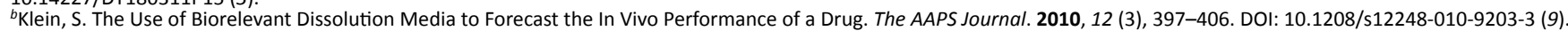
'Good, N. E.; Winget, G. D.; Winter, W.; Connolly, T. N.; Izawa, S.; Singh, R. M. M. Hydrogen lon Buffers for Biological Research. Biochemistry. 1966, 5 (2), 467-477. DOI: 10.1021/ bi00866a011 (16).

${ }^{d}$ Good, N. E.; Izawa, S. Hydrogen Ion Buffers. Methods Enzymol. 1972, 24, 53-68. DOI: 10.1016/0076-6879(72)24054-X (17).

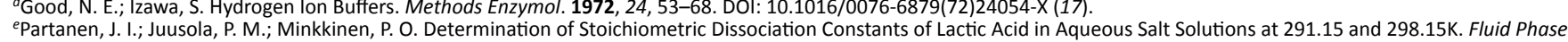
ePartanen, J. I.; Juusola, P. M.; Minkkinen, P. O. Determination of Stoichiometric Dissociation Constants of Lactic Acid in Aqueous Salt Solutions at 291.15 and 298.15K. Fluid Phas
Equilib. 2003, 204, 245-266 (42). fBénézeth, P.; Palmer, D. A.; Wesolowski, D. J. Dissociation Quotients for Citric Acid In Aqueous Sodium Chloride Media to $150{ }^{\circ} \mathrm{C}$. J. Solution Chem. 1997, 26 (1), 63-84. DOI: 10.1007/BF02439444 (43).

gFukada, H.; Takahashi, K. Enthalpy and Heat Capacity Changes for the Proton Dissociation of Various Buffer Components in 0.1 M Potassium Chloride. PROTEINS: Struct., Funct. Genet. 1998, 33 (2), 159-166. DOI:10.1002/(SICI)1097-0134(19981101)33:2<159::AID-PROT2>3.0.CO;2-E (44).

${ }^{h}$ Harned, H. S.; Bonner, F. T. The First lonization Constant of Carbonic Acid in Aqueous Solutions of Sodium Chloride. J. Am. Chem. Soc., 1945, 67 (6), 1026-1031. DOI: 10.1021/ ja01222a037 (25).

ipKa ${ }^{\prime}$ value estimated using data given in Marques et al. Table 7 for FeSSIF middle, temperature not stated (3).

${ }^{j}$ Data from Durst, R. A.; Staples, B. R. Tris/Tris-HCL: A Standard Buffer for Use in the Physiologic pH Range. Clin. Chem. 1972, 18 (3), 206-208 (34).

${ }^{k}$ Additional $\mathrm{pH}$ data for zwitterionic buffers available in:

Roy, L. N.; Roy, R. N.; Wollen, J. T.; Harmon, M. A.; Stegner, J. M.; Shah, A. A.; Henson, I. B. Buffer Standards for the Biological pH of the Amino Acid N-[2hydroxyethyl] piperazine-N'-[3-propanesulfonic acid], HEPPS, From (278.15 to 328.15) K. J. Chem. Eng. Data. 2011, 56 (11), 4126-4132. DOI: 10.1021/je200629y (36) Roy, L. N.; Roy, R. N.; Allen, K. A.; Merhoff, C. J.; Henson, I. B.; Stegner, J. M. Buffer Standards for the Physiological pH of the Zwitterionic Compound of 3-(N-morpholino) propanesulfonic acid (MOPS) from T = (278.15 to 328.15) K. J. Chem. Thermodyn. 2012, 47, 21-27. DOI: 10.1016/j.jct.2011.09.101 (37) Roy, R. N.; Roy, L. N.; Ashkenazi, S.; Wollen, J. T.; Dunseth, C. D.; Fuge, M. S.; Durden, J. L.; Roy, C. N.; Hughes, H. M.; Morris, B. T.; Cline, K. L. Buffer Standards for pH Measurement of N-(2-Hydroxyethyl)piperazine-N'-2-ethanesulfonic Acid (HEPES) for I = 0.16 mol kg-1 from 5 to $55^{\circ} \mathrm{C}$. J. Solution Chem. 2009, 38 (4), $449-458$. Measurement of N-(2-Hydroxyethyl)piperazine-N'-2-ethanesulfonic Acid (HEPES) for I $=0.16 \mathrm{~mol} \mathrm{kg-1}$ from 5 to $55^{\circ} \mathrm{C}$. J. Solution Chem. 2009, 38 (4), $449-458$.
DOI: $10.1007 / \mathrm{s} 10953-009-9378-3$ (38)

Feng, D.; Koch, W. F.; Wu, Y. C. Second Dissociation Constant and pH of N-(2-Hydroxyethyl)piperazine-N'-2-ethanesulfonic Acid from 0 to $50{ }^{\circ} \mathrm{C}$. Anal. Chem. 1989, 61, $1400-1405$ (39)

Roy, L. N.; Roy, R. N.; Wollen, J. T.; Stegner, J. M.; Harmon, M. A.; Martin, M. S.; Bodendorfer, B. M.; Henson, I. B. Calculation of the pH of Buffer Solution of 2-[N-Morpholino]ethanesulfonic Acid (MES) from $5{ }^{\circ} \mathrm{C}$ to $55^{\circ} \mathrm{C}$. Open J. Phys. Chem. 2011, 1, 77-84. DOI:10.4326/ojpc.2011.13011 (40)

Roy, L. N.; Roy, R. N.; Wollen, J. T.; Bwashi, A.; Stegner, J. M.; Downs, Z. M.; Merhoff, C. J.; Bodendorfer, B. M.; Allen, K. A.; Harmon, M. A.; Henson, I. B.

3-[4-(2-Hydroxyethyl)-1-piperazinyl] propanesulfonic Acid (HEPPS) and the pH of Its Buffer Solutions from (278.15 to 328.15) K. J. Chem. Eng. Data. 2010, 55, 1327-1332. DOI: 10.1021/je9006508 (41)

'Bower, V. E.; Bates, R. G. pH Values of the Clark and Lubs Buffer Solutions at $25^{\circ}{ }^{\circ}$ C. J. Res. Natl. Bur. Stand. (U.S.) 1955, 55 (4), 197-200 (45).

${ }^{m} \mathrm{~A}$ review of the definition of the dissociation constant based on hydrogen ion concentration is found in Kennedy, C. D. Ionic Strength and the Dissociation of Acids. Biochem. Educ. 1990, 18 (1), 35-40 (46) and Partanen, J. I.; Kärki, M. H. Determination of the Thermodynamic Dissociation Constant of a Weak Acid by Potentiometric Acid-Base Titration. J. Chem. Educ. 1994, 71 (5), A120-A122 (47).

Abbreviations: HEPES, $N$-2-hydroxyethylpiperazine- $N$ '-ethanesulfonic acid; HEPPS, $N$-2-hydroxyethylpiperazine- $N$ '-propanesulfonic acid; $M E S$, 2-( $N$-morpholino)ethanesulfonic acid; MOPS, 3-(N-morpholino)propanesulfonic acid; TRIS, tris-(hydroxymethyl)-aminomethane. 
a known salt concentration that is biologically relevant, as with isotonic saline (36-41). $\mathrm{pH}$ data measured under these conditions may be useful as a surrogate for pKa' values because the $\mathrm{pH}$ of a buffer solution is an estimate of the buffer pKa' when the ratio of conjugate base to weak acid is $1: 1$.

Avdeef et al. (49) observed that reliable published pKa values measured at $37{ }^{\circ} \mathrm{C}$ and with physiologically relevant ionic strengths are usually not available. This observation, made in connection with weak electrolyte drug molecules, also applies to buffers and underscores the importance of accumulating a body of reliable buffer pKa data relevant to dissolution test conditions and the physicochemical properties of biorelevant dissolution media.

\section{Sufficient Buffer Capacity to Maintain pH Control Throughout the Dissolution Test}

Buffer capacity, $\beta$, as defined by Van Slyke (50), provides a relationship between the total buffer concentration, $C_{b}$, and the $\mathrm{pH}$ and $\mathrm{pKa}$ of the buffer. The maximum buffer capacity, $\beta_{\max }$, occurs when buffer $\mathrm{pH}=$ buffer $\mathrm{pKa}$ :

$$
\beta_{\max }=0.576 C_{b}
$$

For a specific buffer concentration, $C_{b}$, the buffer capacity can be expressed as a percentage of the maximum buffer capacity for units of $\mathrm{pH}=\mathrm{pKa} \pm \mathrm{pH}$. The data in Table 4 exemplify this relationship (20).

Table 4. Percent ${ }_{\beta \max }$ as a Function of $\mathrm{pH}$

\begin{tabular}{|c|c|}
\hline $\mathrm{pH}=\mathrm{pKa} \pm \mathrm{pH}$ & Percent $\boldsymbol{\beta}_{\max }{ }^{a}$ \\
\hline 1.0 & 33.0 \\
\hline 0.7 & 55.4 \\
\hline 0.5 & 73.0 \\
\hline 0.3 & 88.9 \\
\hline 0.0 & 100.0 \\
\hline
\end{tabular}

${ }^{a}$ Data from Perrin, D. D.; Dempsey, B. Buffers for $\mathrm{pH}$ and Metal Ion Control; Chapman and Hall Ltd.: London, 1974; p 21 (20).

Based on Equation 9, there are two approaches to maximizing buffer capacity: (1) increasing total buffer concentration and (2) selecting a buffer where buffer $\mathrm{pH}=$ buffer $\mathrm{pKa}$.

While a calculated value for the intrinsic buffer capacity of the buffer is a useful parameter, it does not reflect buffer $\mathrm{pH}$ and buffer capacity of the simulated biological fluid where sugars (51), salts (52), and other ingredients that affect $\mathrm{pH}$ and buffer capacity are present in the formula.
An estimate of the buffer capacity for the complete formula can be made by:

$$
\beta \approx \Delta \mathrm{A} / \Delta \mathrm{pH} \text { or } \beta \approx \Delta \mathrm{B} / \Delta \mathrm{pH}
$$

where $\Delta A$ and $\Delta B$ are small increments of strong acid or base added to the buffer to produce a $\mathrm{pH}$ change, $\Delta \mathrm{pH}$. Methods to experimentally measure $\beta$ have been discussed by Stippler et al. (53), Ramtoola et al. (54), and Levis et al. (1).

Of ultimate importance is whether the buffer capacity of the simulated biological fluid is sufficient to withstand changes in bulk $\mathrm{pH}$ related to the solubility of the drug substance and any $\mathrm{pH}$ effect from the dosage form excipients $(54,55)$. A practical method to test buffer capacity and $\mathrm{pH}$ control is to measure the $\mathrm{pH}$ of a suspension/solution of the dosage form, including drug and excipients, in a volume of simulated biological fluid that will be used for dissolution test conditions (55).

A significant change in $\mathrm{pH}$ is indicative of an insufficient buffer capacity to maintain $\mathrm{pH}$ control during the dissolution test, which, in turn, can affect the reproducibility of the test results (2). One method of increasing buffer capacity is to increase buffer concentration; however, this approach may be inconsistent with the physicochemical properties of the simulated biological fluid. Garbacz et al. (56) reported on the use of an automated $\mathrm{pH}$-stat system for monitoring and regulating the $\mathrm{pH}$ of bicarbonate buffers; however, the use of a pH-stat adds complexity and requires optimizing additional experimental parameters (57).

Based on this literature review, $\mathrm{pH}$ control is potentially a challenge for biorelevant dissolution media having relatively low buffer capacity (6), and approaches for $\mathrm{pH}$ control are needed that are consistent with the physicochemical properties of the simulated biological fluid, do not contribute to changes in dissolution test conditions that affect test results, and do not add complexity to dissolution test conditions.

\section{Buffer Contribution to the lonic Strength of the Dissolution Media and Buffer pKa Dependence on Temperature and lonic Strength}

As noted by Ellis et al. (18), both ionic strength and temperature modify buffer pKa. The correction of the thermodynamic $\mathrm{pKa}_{1}=0$ for both ionic strength and temperature has been expressed by Beynon et al. (58) as: $\mathrm{pKa}^{\prime}=\mathrm{pKa} \mathrm{a}_{1}=0+$ lonic Strength Correction + Temperature Correction

where each correction term may be positive, negative or zero. The effect of each correction term is discussed in the following sections. 
lonic strength affects the diffusional process for drug dissolution (49) as well as sensitivity to changes in buffer $\mathrm{pH}$ due to dilution effects and the effects of adding salts (52). Additionally, ionic strength is interrelated with the solubility of other dissolved solutes including the drug substance (59).

The ionic strength of the buffer is dependent on the $\mathrm{pH}$ of the solution relative to the pKa of the buffer, the charge on the buffer species, and buffer concentration. Table 5 shows the ionic strength for various buffers at a constant total molar concentration of $50 \mathrm{mM}$ and where the concentration of each buffer species is $25 \mathrm{mM}$. An analysis of these data shows that ionic strength for each buffer varies over the useful buffer $\mathrm{pH}$ range of $\mathrm{pH}=\mathrm{pKa} \pm 1$, the greatest buffer-related contribution to ionic strength is by the phosphate buffer where the ionic strength at $\mathrm{pH}=\mathrm{pKa}$ is greater than the total molar concentration of the buffer by a factor of two $\left(I=1 \times\left[\mathrm{KH}_{2} \mathrm{PO}_{4}\right]+3 \times\left[\mathrm{Na}_{2} \mathrm{HPO}_{4}\right]\right)$, and the smallest contribution to ionic strength is from buffers where one of the buffer species has a charge of zero (e.g., acetate and TRIS, for the acetate buffer at $\mathrm{pH}=\mathrm{pKa}, \mathrm{I}=0$ $\left.x\left[\mathrm{CH}_{3} \mathrm{CO}_{2} \mathrm{H}\right]+1 \times\left[\mathrm{CH}_{3} \mathrm{CO}_{2} \mathrm{Na}\right]\right)$. Therefore, buffers having an uncharged species will minimize buffer contribution to ionic strength across the useful buffer $\mathrm{pH}$ range. Strictly speaking, neutral species such as acetic acid have a finite ionic strength where $\mathrm{I} \approx(\mathrm{Ka} \mathrm{M} M)^{1 / 2}(60)$.

Table 5. Ionic Strength as a Function of Buffer $\mathrm{pH}$ Relative to Buffer $p K a$ (total molar buffer concentration $=50 \mathrm{mM}$, with equimolar concentration of each buffer species)

\begin{tabular}{|c|c|c|c|c|c|}
\hline $\begin{array}{c}\text { Buffer } \\
\text { System }\end{array}$ & $\begin{array}{c}\text { Charge } \\
\text { on the } \\
\text { acid } \\
(\mathrm{z}+1)\end{array}$ & $\begin{array}{c}\text { Charge } \\
\text { on the } \\
\text { conjugate } \\
\text { base }(\mathrm{z})\end{array}$ & \multicolumn{4}{|c|}{ Ionic Strength ${ }^{a}(\mathrm{mM})$} \\
\hline & & & $\mathrm{pH}=\mathrm{pKa}-1$ & $\mathrm{pH}=\mathrm{pKa}$ & $\mathrm{pH}=\mathrm{pKa}+1$ \\
\hline $\begin{array}{c}\mathrm{CH}_{3} \mathrm{CO}_{2} \mathrm{H} / \\
\mathrm{CH}_{3} \mathrm{CO}_{2} \mathrm{Na}\end{array}$ & 0 & -1 & 4.55 & 25 & 45.5 \\
\hline $\begin{array}{c}\mathrm{MES} \pm \\
\mathrm{NaMES}\end{array}$ & 0 & -1 & 4.55 & 25 & 45.5 \\
\hline $\begin{array}{c}\mathrm{TRIS} / \mathrm{TRIS}- \\
\mathrm{HCL}\end{array}$ & +1 & 0 & 45.5 & 25 & 4.55 \\
\hline $\begin{array}{c}\mathrm{KH}_{2} \mathrm{PO}_{4} / \\
\mathrm{Na}_{2} \mathrm{HPO}_{4}\end{array}$ & -1 & -2 & 59.1 & 100 & 140.9 \\
\hline
\end{tabular}

alonic strength calculated using Equation 8.

Abbreviations: MES, 2-( $N$-morpholino)ethanesulfonic acid; TRIS, tris(hydroxymethyl)-aminomethane.

For example, the ionic strength of a $0.01 \mathrm{M}$ solution of acetic acid ( $\mathrm{Ka}=10^{-4.76}$ ) is approximately 4.2E-04 compared with the ionic strength of a $0.01 \mathrm{M}$ solution of sodium acetate, which is 0.01 . According to Roy et al. (36) and Stellwagen et al. (61), zwitterionic species, such as MES \pm , do not contribute to the ionic strength of an aqueous solution. As noted by Blanchard (10) and Stoll (11), the lowest possible buffer concentration is preferable to avoid nonspecific ionic strength effects on enzymes and other dissolved solutes in the media.

Svensson (62) discussed a classification of buffers known as isoelectric buffers, with histidyl-glycine being an example. These buffers have negligible ionic strength at their isoionic point, pl, while having finite buffer capacity if they meet the criterion that $\left(\mathrm{pl}-\mathrm{pK}_{\mathrm{a1}}\right)<1.5(63)$.

The ionic strength of the buffer affects the buffer pKa' via the following relationship (18):

$$
\mathrm{pKa}^{\prime}=\mathrm{pKa}_{\mathrm{l}}=0+(2 \mathrm{z}+1)\left[\left(\mathrm{A} \times \mathrm{I}^{1 / 2}\right) /\left(1+1^{1 / 2}\right)-0.1 \times \mathrm{l}\right]
$$

where $p K a_{1}=0$ is the thermodynamic pKa at a specified temperature and $A$ is a temperature-dependent constant that is close to 0.5 for the temperature rangeof $25-37{ }^{\circ} \mathrm{C}$. The exact value for $\mathrm{A}$ is dependent on the dielectric constant of water, $\epsilon$, at temperature $T$ (Kelvin) where $A=1.825 \mathrm{EO}(\epsilon \mathrm{T})^{-3 / 2}(64)$. At $25^{\circ} \mathrm{C}, \mathrm{A}=0.5115$ and $\epsilon=74.3$; at $37^{\circ} \mathrm{C}, \mathrm{A}=0.5233$ and $\epsilon=74.2$. The equation relating dielectric constant with temperature is given by:

$\epsilon=87.740-0.40008 t+9.398 \mathrm{E}-04 t^{2}-1.410 \mathrm{E}-06 t^{3}\left(t^{\circ} \mathrm{C}\right)(65)$.

For example, the estimated pKa2' for a phosphate buffer, $\mathrm{z}=-2$, at $25^{\circ} \mathrm{C}$ with $\mathrm{I}=0.1$ is:

$\mathrm{pKa}_{2}{ }^{\prime}=7.198+(-3)\left[\left(0.5115 \times 0.1^{1 / 2}\right) /\left(1+0.1^{1 / 2}\right)-0.1 \times 0.1\right]=6.86$.

Based on this estimate of $\mathrm{pKa}_{2}{ }^{\prime}$, the expected $\mathrm{pH}$ for a buffer with equal concentrations of $\mathrm{H}_{2} \mathrm{PO}_{4}^{-1}$ and $\mathrm{HPO}_{4}{ }^{-2}$ and $\mathrm{I}=0.1$ is 6.86 . By comparison, the measured $\mathrm{pH}$ is 6.865 for a primary standard phosphate buffer containing 0.025 molal $\mathrm{H}_{2} \mathrm{PO}_{4}{ }^{-1}$ and 0.025 molal $\mathrm{HPO}_{4}{ }^{-2}$ $(I=0.1)$ at $25^{\circ} \mathrm{C}(66)$.

Two other factors involving ionic strength affect the $\mathrm{pH}$ of biorelevant dissolution media. The first factor is related to diluting stock solutions of buffer to a lower biorelevant concentration and the second factor is related to the addition of salts to adjust the osmotic pressure of the buffered media. First, an example showing the effect of dilution: $50 \mathrm{mM}$ phosphate buffer, initial $\mathrm{pH} 6.772$, increases to $\mathrm{pH} 7.018$ when diluted to $5 \mathrm{mM}$ at $25^{\circ} \mathrm{C}(28)$. Therefore, the $\mathrm{pH}$ of USP $50 \mathrm{mM}$ phosphate buffer can be expected to change when diluted for use as a surrogate buffer (6). And second, an example showing the effect of adding a neutral salt to a phosphate buffer: a $50 \mathrm{mM}$ phosphate buffer, $I=0.1$, when changed to $I=0.2$ by the addition of sodium chloride, results in a change in $\mathrm{pH}$ of $-0.88 \mathrm{pH}$ units (52). Both the dilution and salt addition effects are primarily related to ionic strength (52) and 
can be minimized by fixing the total ionic strength at a constant and biologically relevant level, such as isotonic conditions, with a salt.

Ellis et al. (18) provide a temperature-pKa correction via the following relationship:

$$
p K a_{R T}=p K a_{T}+(R T-T) D T
$$

where $\mathrm{RT}$ is the required temperature, $\mathrm{T}$ is the temperature at which the measurement is made, and DT is the change in pKa per degree change in temperature, dpKa/dT.

Values for dpKa/dT for the buffers in Table 3 are given in Table 2. These values were calculated using the van't Hoff Equation (32) at $\mathrm{T}=298.15 \mathrm{~K}\left(25^{\circ} \mathrm{C}\right)$, with literature values for the enthalpy of ionization measured at $\mathrm{T}=298.15 \mathrm{~K}$ and at $\mathrm{I}=0$ for each buffer system.

A comprehensive listing of enthalpy of ionization and other thermodynamic quantities for the ionization reaction of buffers is available in Goldberg et al. (21). An analysis of these data show that the rank order of temperature dependence by buffer grouping is:

(TRIS) > zwitterionic buffers > phosphate buffer > carboxylic acid buffers.

The pKa of carboxylic acid buffers is nearly invariant with temperature. By comparison, the pKa for TRIS buffers is more temperature sensitive than the acetate buffer by approximately two orders of magnitude.

A review of the literature points to physicochemical considerations related to the selection of a buffer. Buffers with an uncharged species will minimize buffer contribution to ionic strength across the useful buffer $\mathrm{pH}$ range; primary amine buffers, such as TRIS, have a significant change in pKa with a change in temperature while carboxylic acid buffers have a negligible pKatemperature dependence; and buffers are susceptible to $\mathrm{pH}$ change due to dilution and the effect of added salts primarily because of ionic strength effect.

Compatibility Between the Buffer and Other Components in the Biorelevant Dissolution Media

Compatibility is an important buffer characteristic made more complex because of the diversity of ingredients in dissolution media including salts of divalent cations, sugars, bovine serum albumin, enzymes, and surfactants. Table 6 lists the buffer ingredient, the potential incompatibility or interaction with other components of the biorelevant buffer, and the literature evaluation (4, 13-15, 58, 67-70). The literature points to the compatibility of zwitterionic buffers with metal ions and to potential incompatibilities between polyvalent cations with phosphate and citrate buffers.

Low Absorbance Spectra in UV and Visible Regions

Zwitterionic buffers were designed to not absorb light in the visible or ultraviolet region of the spectrum. Good et al. (16) report that $0.05 \mathrm{M}$ solutions of MES and $\mathrm{N}-2$ hydroxyethylpiperazine- $N$ '-ethanesulfonic acid (HEPES) absorbed a negligible amount at wavelengths greater than $240 \mathrm{~nm}$ and very little light at $230 \mathrm{~nm}$. Similar properties are expected for 3-( $\mathrm{N}$-morpholino) propanesulfonic acid (MOPS) and N-2-hydroxyethylpiperazine $-N$ 'propanesulfonic acid (HEPPS) given the chemical similarity of MOPS to MES and HEPPS to HEPES. Xu (48) used the HEPES buffer in a two-stage reverse dialysis method for in vitro release testing and did not report any interference from the buffer with a high-performance liquid chromatography (HPLC) assay where the analyte was detected at $260 \mathrm{~nm}$. Ment et al. (71) report that a low assay value for an antihistamine maleate salt was due to the chromophoric properties of maleic acid.

Perrin et al. (20) provide a table of buffers that have been developed for use in spectrophotometry, which includes those commonly used in simulated biological fluids, such as acetate, phosphate, citrate, carbonate, and TRIS. Singh et al. (72) describe the successful development and validation of a new HPLC method for the estimation of fluconazole in different simulated biological fluids (e.g., gastric, vaginal, and blood plasma).

\section{Buffer Effect on Drug Solubility}

The buffer may affect drug solubility from $\mathrm{pH}$-solubility relationships (1), common ion effect (73), and buffer concentration/ionic strength effects (59). Additionally, other ingredients in the bioequivalent dissolution media, such as surface-active agents and bile salts, may affect drug solubility. Any influence that the buffer or bioequivalent dissolution media has on drug solubility will be reflected in the dissolution rate as shown by Equation 14:

$$
\text { Dissolution Rate }=\mathrm{k}\left(\mathrm{C}_{\mathrm{sat}}-\mathrm{C}_{t}\right)
$$

where $C_{t}$ is the concentration of dissolved drug at time $t, C_{\text {sat }}$ is the concentration of a saturated solution of the drug at a specified temperature and $\mathrm{k}$ is a constant (74). Therefore, $\mathrm{C}_{\text {sat }}$, the equilibrium solubility at a specified temperature, is an important parameter needed to estimate the effect of the buffer and the dissolution media on drug solubility and dissolution rate.

In summary, Dressman et al. (75) emphasize the equilibrium solubility of the drug in biorelevant dissolution media is dependent on the properties of the media, and 
Table 6. Evaluation of Potential Incompatibilities and Interactions Between Buffer Ingredients and Other Components of Biorelevant Dissolution Media

\begin{tabular}{|c|c|c|}
\hline Buffer/Buffer Ingredient & Potential Interaction/Incompatibility & Literature Evaluation \\
\hline TRIS & $\begin{array}{l}\text { Reactive primary amine with potential for Schiff } \\
\text { Base formation with aldehydes and ketones }\end{array}$ & $\begin{array}{l}\text { A reaction that can be responsible for an } \\
\text { incompatibility with reducing sugars (e.g., } \\
\text { glucose, lactose) })^{a}\end{array}$ \\
\hline TRIS & $\begin{array}{l}\text { Interaction with metal ions }\left(\mathrm{Mg}^{+2}, \mathrm{Ca}^{+2}, \mathrm{Ba}^{+2}\right. \\
\left.\mathrm{Mn}^{+2}, \mathrm{Co}^{+2}, \mathrm{Ni}^{+2}, \mathrm{Cu}^{+2}, \mathrm{Zn}^{+2}, \mathrm{Cd}^{+2} \text { and } \mathrm{Pb}^{+2}\right)\end{array}$ & $\begin{array}{c}\text { Reservation should be exercised in employing } \\
\text { TRIS as a buffer system which also contains } \\
\text { metal ions }{ }^{b}\end{array}$ \\
\hline Phosphate & $\begin{array}{l}\text { Interaction with divalent ions (e.g., } \mathrm{Ca}^{+2} \text { ) to form } \\
\text { insoluble precipitate }\end{array}$ & $\begin{array}{l}\text { When } \mathrm{CaC}_{12} \text { is added to a phosphate buffer } \\
\text { a phosphate salt often precipitates, affecting } \\
\text { free } \mathrm{Ca}^{+2} \text { ion concentration, phosphate ion } \\
\text { concentration, and } \mathrm{pH}^{c}\end{array}$ \\
\hline MES, MOPS, HEPES, HEPPS & Interaction with metals & $\begin{array}{l}\text { Evaluated as being suitable to use with metals } \\
\left(\mathrm{Mg}^{+2}, \mathrm{Ca}^{+2}, \mathrm{Cr}^{+3}, \mathrm{Mn}^{+2}, \mathrm{Fe}^{+3}, \mathrm{Co}^{+2}, \mathrm{Ni}^{+2}, \mathrm{Cu}^{+2}, \mathrm{Zn}^{+2}\right. \\
\left.\qquad \mathrm{Cd}^{+2}, \mathrm{~Pb}^{+2}\right)^{d}\end{array}$ \\
\hline Potassium salt of the phosphate buffer & Interaction with sodium dodecyl sulfate (SDS) & $\begin{array}{l}\text { Precipitate forms when the potassium salt of } \\
\text { the phosphate buffer is used at a concentration } \\
\text { of } 0.5 \mathrm{M} \text { in combination with SDS; the problem } \\
\text { is avoided by using the sodium phosphate salt } \\
\text { when preparing the media with SDS }\end{array}$ \\
\hline MES, MOPS & $\begin{array}{l}\text { Interaction with macromolecules (e.g., bovine } \\
\text { serum albumin) }\end{array}$ & $\begin{array}{c}\text { Interacts with peptide backbone of bovine serum } \\
\text { albumin leading to a net stabilization of } \\
\text { the protein }\end{array}$ \\
\hline Citric acid & Interaction with $\mathrm{Ca}^{+2}$ & $\begin{array}{l}\text { Half neutralized citric acid interacts with } \mathrm{CaCl}_{2} \\
\text { resulting in a significant decrease in } \mathrm{pH} \text { due to } \\
\text { released hydrogen ions: } \mathrm{AH}=5.93 \text { (initial) to } \\
4.65(\text { final) })^{g} \text {. The solubility of calcium citrate is } \\
\mathrm{pH} \text { dependent }{ }^{h}\end{array}$ \\
\hline Maleate & Interaction with proteins & $\begin{array}{c}\text { The }-\mathrm{SH} \text { bonds of proteins or free thiols can add } \\
\text { across the double bond of maleic acid to produce } \\
\text { proteins that are irreversibly modified by } \\
\text { this reagent }{ }^{i}\end{array}$ \\
\hline
\end{tabular}

${ }^{a}$ Wu, Y.; Levons, J.; Narang, A. S.; Raghavan, K.; Rao, V. M. Reactive Impurities in Excipients: Profiling, Identification and Mitigation of Drug-Excipient Incompatibility. AAPS PharmSciTech. 2011, 12 (4), 1248-1263. DOI: 10.1028/s12249-011-9677-z (67).

${ }^{b}$ Fisher, B. E.; Haring, U. K.; Tribolet, R.; Sigel, H. Metal Ion/Buffer Interactions. Stability of Binary and Ternary Complexes Containing 2-Amino -2(hydroxymethyl)-1,3-propanediol (Tris) and Adenosine 5'-Triphosphate (ATP). Eur. J. Biochem. 1979, 94, 523-530 (68).

cPark, Y.; Kim, S. H.; Matalon, S.; Wang, N-H. L.; Franses, E. I. Effect of Phosphate Salt Concentrations, Supporting Electrolytes, and Calcium Phosphate Salt Precipitation on the pH of Phosphate Salt Solutions. Fluid Phase Equilib. 2009, 278, 76-84. DOI: 10.1016/j.fluid.2009.01.005 (15).

${ }^{d}$ Ferreira, C. M. H.; Pinto, I. S. S.; Soares, E. V.; Soares, H. M. V. M. (Un)Suitability of the Use of pH Buffers in Biological, Biochemical, and Environmental Studies and Their Interaction With Metal Ions-A Review. RCS Adv. 2015, 5, 30989-31003. DOI: 10.1039/c4ra15453c (13).

${ }^{e}$ The United States Pharmacopeia and National Formulary USP 39 -NF 34; The United States Pharmacopeial Convention, Inc.: Rockville, MD, USA, 2016 (4). fTaha, M.; Gupta, B. S.; Khoiroh, I; Lee, M-J. Interactions of Biological Buffers: The Ubiquitous "Smart" Polymer PNIPAM and the Biological Buffers, MES, MOPS and MOPSO. Macromolecules. 2011, 44, 8575-8589. DOI:10.1021/ma201790c (69).

${ }^{g}$ Greenwald, I. The Dissociation of Some Calcium Salts. J. Biol. Chem. 1938, 124, 437-452 (70).

${ }^{h}$ Goss, S. L.; Lemons, K. A.; Kerstetter, J. E.; Bogner, R. H. Determination of Calcium Salt Solubility with Changes in pH and Pco2, Simulating Varying Gastrointestinal Environments. J. Pharm. Pharmacol. 2007, 59, 1485-1492. DOI: 10.1211/jpp.59.11.0004 (14).

'Beynon, R. J.; Easterby, J. S. Buffer Solutions - The Basics; IRL PRESS at Oxford University Press: Oxford, 1996; p 77 (58).

Abbreviations: HEPPS, $N$-2-hydroxyethylpiperazine- $N$ '-propanesulfonic acid; HEPES, $N$-2-hydroxyethylpiperazine- $N$ '-ethanesulfonic acid; MES, 2-(N-morpholino)ethanesulfonic acid; MOPS, 3-( $N$-morpholino)propanesulfonic acid; TRIS, tris-(hydroxymethyl)-aminomethane. 
aqueous solubility is not predictive of the solubility in these simulated fluids. This statement applies to the need to determine drug solubility in buffered bioequivalent dissolution media when evaluating experimental conditions for dissolution testing.

\section{Nonreactivity with Atmospheric Gases}

According to Perrin et al. (20), a difficulty related to using bicarbonate $/ \mathrm{CO}_{2}$ buffers is the need to use a closed system to maintain $\mathrm{pH}$ control. Persat et al. (76) point to a problem with weak base buffers such as TRIS where the $\mathrm{pH}$ of a diluted buffer can be affected by dissolved $\mathrm{CO}_{2}$. Persat et al. (76) also note that $\mathrm{CO}_{2}$ can react with uncharged primary and secondary amine components of buffers to form carbamate ions. The extent to which carbamate ions affect the dissolution process is unknown.

\section{Safety and Toxicity}

All buffers listed in Tables 2 and 3 are available commercially with material data safety sheets. Several reagents used to prepare the buffers listed in Tables 2 and 3 are referenced in the Select Committee on GRAS Substances Database (http://www.accessdata.fda.gov/ scripts/fdcc/?set=SCOGS). Most of the anionic buffers listed in Table 3 (e.g., acetate, citrate, bicarbonate/ carbonate, lactate, maleate, and phosphate) have U.S. Food and Drug Administration approval as counter-ions for pharmaceutical salts (77), with safety and toxicology information for these anions being available in the Handbook of Pharmaceutical Salts (78).

\section{A Note on Reporting Buffers}

The protocol for reporting the buffer component of the dissolution media varies as evidenced by the following reporting formats: (1) "pH 4.5 acetate buffer" (79), and (2) "Sorenson PBS pH 7.4 buffer, $\mathrm{NaH}_{2} \mathrm{PO}_{4} \cdot 2 \mathrm{H}_{2} \mathrm{O}$ $13.46 \mathrm{mM}, \mathrm{Na}_{2} \mathrm{HPO}_{4} .12 \mathrm{H}_{2} \mathrm{O} 53.31 \mathrm{mM}, \mathrm{NaCl} 74.27$ $\mathrm{mM}^{\prime \prime}$ (1). The second example is consistent with the recommendation of Mooney et al. (80) to report both the buffer composition and concentration in addition to $\mathrm{pH}$.

Pfannkoch (81) comments on the importance of having completely documented information to be able to reproduce the buffer including the grade of water used, the $\mathrm{pH}$ of the starting water source, and whether the $\mathrm{pH}$ adjustment was done before or after the solution was brought to final volume. Persat et al. (76) recommend reporting the following items: (1) the temperature at which the $\mathrm{pH}$ was measured, (2) the $\mathrm{pH}$ after dilution if the buffer was prepared from a stock solution, and (3) the manufacturer and model of the $\mathrm{pH}$ meter. When reporting pKa values, Prankerd (82) notes the importance of data reliability and reviews the system used by the
International Union of Pure and Applied Chemistry. This system describes pKa values as being "very reliable" ( $p K a$ error < \pm 0.005 ); "reliable" (pKa error \pm 0.005 to \pm 0.02 ); "approximate" (pKa error \pm 0.02 to \pm 0.04 ); and "uncertain" (pKa error $> \pm 0.04$ ).

The USP format (4) provides a standardized protocol that includes the chemical composition, concentration of each buffer species, and $\mathrm{pH}$; the chemical composition and concentration of other buffer reagents such as salts; the method of preparation so that the final concentration of each reagent is known; and water-related specifications. USP <791> also provides information about calibration and operation of the $\mathrm{pH}$ measurement system.

\section{CONCLUSIONS}

This literature review confirms that buffers play a central role in $\mathrm{pH}$ control and that $\mathrm{pH}$ stability is particularly important to dissolution test conditions because it affects data reproducibility and interpretation. The literature points to several practical considerations related to buffer selection, which are summarized as follows:

1. Maintaining pH stability due to low buffer capacity and potential compatibility problems between the buffer and reagents in the simulated biological fluid are among the challenges that can be identified for buffers used with biorelevant dissolution media.

2. Attributes for selecting buffer components for biorelevant dissolution media, like those originally outlined by Good et al. $(16,17)$, may prove useful in selecting a buffer for a dissolution-related application.

3. Buffer-related ionic strength effects can be minimized by selecting a buffer where one of the buffer species has a zero charge, such as acetic acid or a zwitterionic buffer.

4. Buffers containing a primary amine, such as TRIS, can interact with reducing sugars in biorelevant dissolution media.

5. Phosphate, citrate, and TRIS buffers can interact with polyvalent cations to form insoluble precipitates.

6. Buffer pKa-temperature effects can be minimized by avoiding primary amine buffers, such as TRIS.

7. Zwitterionic buffers like MES, MOPS, HEPPS, and HEPES have been characterized as having negligible reactivity with metals.

8. Except for maleic acid, other buffers commonly used in dissolution media have low absorbance in the UV and visible region of the spectrum.

9. TRIS may interact with bicarbonate $/ \mathrm{CO}_{2}$ buffer systems. 
The literature suggests three areas that merit consideration in the continuing evolution of buffers used for biorelevant dissolution media: (1) development of methods to maintain $\mathrm{pH}$ control for biorelevant dissolution media having low buffer capacity, (2) development of a literature base containing $\mathrm{pH}$ and $\mathrm{pKa}$ values of buffers measured under conditions related to biorelevant dissolution media and under dissolution test conditions where the temperature is $37{ }^{\circ} \mathrm{C}$, and 3) continued evaluation of zwitterionic buffers designed for biological application that provide an opportunity to enlarge the library of buffers traditionally used for $\mathrm{pH}$ control of biorelevant dissolution media.

\section{CONFLICT OF INTEREST}

The authors declare no conflict of interest.

\section{ACKNOWLEDGMENTS}

The author would like to thank Dr. Dennis H. Robinson for his careful reading of this paper and his valuable insights and comments.

\section{REFERENCES}

1. Levis, K. A.; Lane, M. E.; Corrigan, O. I. Effect of Buffer Media Composition on the Solubility and Effective Permeability Coefficient of Ibuprofen. Int. J. Pharm. 2003, 253, 49-59. DOI: 10.1016/S0378-5173(02)00645-2.

2. Dressman, J. Evolution of Dissolution Media Over the Last Twenty Years. Dissolution Technol. 2014, 21 (3), 6-10. DOI: 10.14227/ DT210314P6.

3. Marques, M. R. C.; Loebenberg, R.; Almukainzi, M. Simulated Biological Fluids with Possible Application in Dissolution Testing. Dissolution Technol. 2011, 18 (3), 15-28. DOI: 10.14227/ DT180311P15.

4. The United States Pharmacopeia and National Formulary USP 39 -NF 34; The United States Pharmacopeial Convention, Inc.: Rockville, MD, USA, 2016.

5. Sheng, J. J.; McNamara, D. P.; Amidon, G. L. Toward an In Vivo Dissolution Methodology: A Comparison of Phosphate and Bicarbonate Buffers. Mol. Pharmaceutics. 2009, 6 (1), 29-39. DOI: 10.1021/mp800148u.

6. Krieg, B. J.; Taghavi, S. M.; Amidon, G. L.; Amidon, G. E. In Vivo Predictive Dissolution: Comparing the Effect of Bicarbonate and Phosphate Buffer on the Dissolution of Weak Acids and Weak Bases. J. Pharm. Sci. 2015, 104, 2894-2904. DOI: 10.1002/ jps. 24460

7. Baicu, S. C.; Taylor, M. J. Acid-Base Buffering in Organ Preservation Solutions as a Function of Temperature: New Parameters for Comparing Buffer Capacity and Efficiency. Cryobiology. 2002, 45, 33-48. DOI: 10.1016/S0011-2240(02)00104-9.

8. Rastogi, R.; Su, J.; Mahalingam, A.; Clark; J.; Sung; S.; Hope, T.; Kiser, P. Engineering and Characterization of Simplified Vaginal and Seminal Fluid Simulants. Contraception. 2016, 93, 337-346. DOI: 10.1016/j.contraception.2015.11.008.
9. Klein, S. The Use of Biorelevant Dissolution Media to Forecast the In Vivo Performance of a Drug. The AAPS Journal. 2010, 12 (3), 397-406. DOI: 10.1208/s12248-010-9203-3.

10. Blanchard, J. S. Buffers for Enzymes. Methods in Enzymol. 1984, 104, 404-414. DOI: 10.1016/S0076-6879(84)04107-0.

11. Stoll, V. S.; Blanchard, J. S. Buffers: Principles and Practice. Methods in Enzymol. 1990, 182, 24-38. DOI: 10.1016/00766879(90)82006-N.

12. Zhang, F.; Skoda, M.; Jacobs, R. M.; Martin, R. A.; Martin, C. M.; Schreiber, F. Protein Interactions Studied by SAXS: Effect of Ionic Strength and Protein Concentration for BSA in Aqueous Solutions. J. Phys. Chem. B. 2007, 111, 251-259. DOI: 10.1021/jp0649955.

13. Ferreira, C. M. H.; Pinto, I. S. S.; Soares, E. V.; Soares, H. M. V. M. (Un)Suitability of the Use of pH Buffers in Biological, Biochemical, and Environmental Studies and Their Interaction With Metal lons-A Review. RCS Adv. 2015, 5, 30989-31003. DOI: 10.1039/ c4ra15453c.

14. Goss, S. L.; Lemons, K. A.; Kerstetter, J. E.; Bogner, R. H. Determination of Calcium Salt Solubility with Changes in $\mathrm{pH}$ and $\mathrm{PCO}_{2}$, Simulating Varying Gastrointestinal Environments. J. Pharm. Pharmacol. 2007, 59, 1485-1492. DOI: 10.1211/ jpp.59.11.0004.

15. Park, Y.; Kim, S. H.; Matalon, S.; Wang, N-H. L.; Franses, E. I. Effect of Phosphate Salt Concentrations, Supporting Electrolytes, and Calcium Phosphate Salt Precipitation on the $\mathrm{pH}$ of Phosphate Salt Solutions. Fluid Phase Equilib. 2009, 278, 76-84. DOI: 10.1016/j. fluid.2009.01.005.

16. Good, N. E.; Winget, G. D.; Winter, W.; Connolly, T. N.; Izawa, S.; Singh, R. M. M. Hydrogen Ion Buffers for Biological Research. Biochemistry. 1966, 5 (2), 467-477. DOI: 10.1021/bi00866a011.

17. Good, N. E.; Izawa, S. Hydrogen Ion Buffers. Methods Enzymol. 1972, 24, 53-68. DOI: 10.1016/0076-6879(72)24054-X.

18. Ellis, K. J.; Morrison, J. F. Buffers of Constant lonic Strength for Studying pH-Dependent Processes. Methods Enzymol. 1982, 87, 405-426. DOI: 10.1016/S0076-6879(82)87025-0.

19. Butler, J. N. Ionic Equilibrium. Solubility and $\mathrm{pH}$ Calculations; John Wiley \& Sons: New York, 1998; pp 130-133.

20. Perrin, D. D.; Dempsey, B. Buffers for $\mathrm{pH}$ and Metal Ion Control; Chapman and Hall Ltd.: London, 1974.

21. Goldberg, R. N.; Kishore, N.; Lennen, R. M. Thermodynamic Quantities for the lonization Reactions of Buffers. J. Phys. Chem. Ref. Data. 2002, 31 (2), 231-370. DOI: 10.1063/1.1416902.

22. Nims, L. F.; Smith, P. K. The lonization of Lactic Acid from Zero to Fifty Degrees. J. Biol. Chem. 1936, 113, 145-152.

23. Bates, R. G.; Pinching, G. D. Resolution of the Dissociation Constants of Citric Acid at 0 to $50^{\circ}$, and Determination of Certain Related Thermodynamic Functions. J. Am. Chem. Soc. 1949, 71, 1274-1283. DOI: 10.1021/ja0117a039.

24. Harned, H. S.; Ehlers, R. W. The Dissociation of Acetic Acid from 0 to $60^{\circ}$ Centigrade. J. Am. Chem. Soc. 1933, 55 (2), 652-656. DOI: 10.10.21/ja01329a027.

25. Harned, H. S.; Bonner, F. T. The First Ionization Constant of 
Carbonic Acid in Aqueous Solutions of Sodium Chloride. J. Am. Chem. Soc., 1945, 67 (6), 1026-1031. DOI: 10.1021/ja01222a037.

26. Das, R. C. Thermodynamics of DL-Malic, Maleic and Fumaric Acids in Water and Water + Dioxan Mixtures. J.C.S. Faraday I. 1980, 76, 2152-2158.

27. Bates, R. G.; Hetzer, H. G. Dissociation Constant of the Protonated Acid Form of 2-Amino-2-(Hydroxymethyl)-1,3-Propanediol [TRISHydroxymethyl)-Aminomethane] and Related Thermodynamic Quantities from 0 to $50^{\circ} \mathrm{C}$. J. Phys. Chem. 1961, 65 (4), 667-671. DOI: $10.1021 / \mathrm{j} 100822 \mathrm{a} 017$.

28. Bates, R. G.; Acree, S. F. pH of Aqueous Mixtures of Potassium Dihydrogen Phosphate and Disodium Hydrogen Phosphate at $0^{\circ}$ to $60^{\circ}$ C. J. Res. Natl. Bur. Std. (U.S.) 1945, 34, 373-394.

29. Vega, C. A.; Bates, R. G. Buffers for the Physiological pH Range: Thermodynamic Constants of Four Substituted Aminoethanesulfonic Acids from 5 to $50^{\circ} \mathrm{C}$. Anal. Chem. 1976, 48 (9), 1293-1296. DOI: 10.1021/ac50003a010.

30. Sankar, M.; Bates, R. G. Buffers for the Physiological pH Range: Thermodynamic Constants of 3-(N-Morpholino)propanesulfonic Acid from 5 to $50^{\circ} \mathrm{C}$. Anal. Chem. 1978, 50 (13), 1922-1924.

31. Roy, R. N.; Moore, C. P.; Lord, P.; Mrad, D.; Roy, L. N.; Good, W. S.; Niederschmidt, J.; Kuhler, K. M. Thermodynamic Constants of $N$-(2-hydroxyethyl) piperazine- $N$ '-3-propanesulfonic acid (HEPPS) and (3-[N-morpholinol])-2-hydroxypropanesulfonic acid (MOPSO) from Temperatures $278.15 \mathrm{~K}$ to $328.15 \mathrm{~K}$. J. Chem. Thermodyn. 1997, 29, 1323-1331.

32. Roig, T.; Bäckman, P.; Olofsson, G. Ionization Enthalpies of Some Common Zwitterionic Hydrogen-Ion Buffers (HEPES, PIPES, HEPPS and BES) for Biological Research. Acta Chemica Scandinavica, 1993, 47, 899-901.

33. Bates, R. G.; Vega, C. A.; White, D. R. Standards for $\mathrm{pH}$ Measurement in Isotonic Saline Media of Ionic Strength I = 0.16. Anal. Chem. 1978, 50 (9), 1295-1300.

34. Durst, R. A.; Staples, B. R. Tris/Tris-HCL: A Standard Buffer for Use in the Physiologic pH Range. Clin. Chem. 1972, 18 (3), 206-208.

35. Reppas, C.; Karatza, E.; Goumas, C.; Markopoulos, C.; Vertzoni, M. Characterization of Distal Ileum and Cecum to Which Drug/ Drug Products are Exposed During Bioavailability/Bioequivalence Studies in Healthy Adults. Pharm. Res. 2015, 32, 3338-3349. DOI: 10.1007/s11095-015-1710-6.

36. Roy, L. N.; Roy, R. N.; Wollen, J. T.; Harmon, M. A.; Stegner, J. M.; Shah, A. A.; Henson, I. B. Buffer Standards for the Biological $\mathrm{pH}$ of the Amino Acid $N$-[2hydroxyethyl]piperazine- $N$ '-[3propanesulfonic acid], HEPPS, From (278.15 to 328.15) K. J. Chem. Eng. Data. 2011, 56 (11), 4126-4132. DOI: 10.1021/je200629y.

37. Roy, L. N.; Roy, R. N.; Allen, K. A.; Merhoff, C. J.; Henson, I. B.; Stegner, J.M. Buffer Standards for the Physiological pH of the Zwitterionic Compound of 3-(N-morpholino)propanesulfonic acid (MOPS) from T = (278.15 to 328.15)K. J. Chem. Thermodyn. 2012, 47, 21-27. DOI: 10.1016/j.jct.2011.09.101.
38. Roy, R. N.; Roy, L. N.; Ashkenazi, S.; Wollen, J. T.; Dunseth, C. D.; Fuge, M. S.; Durden, J. L.; Roy, C. N.; Hughes, H. M.; Morris, B. T.; Cline, K.L. Buffer Standards for pH Measurement of $\mathrm{N}$-(2Hydroxyethyl)piperazine- $N$ '-2-ethanesulfonic Acid (HEPES) for I $=0.16 \mathrm{~mol} \mathrm{~kg}-1$ from 5 to $55^{\circ} \mathrm{C}$. J. Solution Chem. 2009, 38 (4), 449-458. DOI: 10.1007/s10953-009-9378-3.

39. Feng, D.; Koch, W. F.; Wu, Y. C. Second Dissociation Constant and $\mathrm{pH}$ of $\mathbf{N}$-(2-Hydroxyethyl)piperazine- $\mathrm{N}^{\prime}$-2-ethanesulfonic Acid from 0 to $50^{\circ} \mathrm{C}$. Anal. Chem. 1989, 61, 1400-1405.

40. Roy, L. N.; Roy, R. N.; Wollen, J. T.; Stegner, J. M.; Harmon, M. A.; Martin, M. S.; Bodendorfer, B. M.; Henson, I. B. Calculation of the $\mathrm{pH}$ of Buffer Solution of 2-[N-Morpholino]ethanesulfonic Acid (MES) from $5{ }^{\circ} \mathrm{C}$ to $55^{\circ} \mathrm{C}$. Open J. Phys. Chem. 2011, 1, 77-84. DOI:10.4326/ojpc.2011.13011.

41. Roy, L. N.; Roy, R. N.; Wollen, J. T.; Bwashi, A.; Stegner, J. M.; Downs, Z. M.; Merhoff, C. J.; Bodendorfer, B. M.; Allen, K. A.; Harmon, M. A.; Henson, I.B. 3-[4-(2-Hydroxyethyl)-1-piperazinyl] propanesulfonic Acid (HEPPS) and the $\mathrm{pH}$ of Its Buffer Solutions from (278.15 to 328.15) K. J. Chem. Eng. Data. 2010, 55, 13271332. DOI: 10.1021/je9006508.

42. Partanen, J. I.; Juusola, P. M.; Minkkinen, P. O. Determination of Stoichiometric Dissociation Constants of Lactic Acid in Aqueous Salt Solutions at 291.15 and 298.15K. Fluid Phase Equilib. 2003, 204, 245-266.

43. Bénézeth, P.; Palmer, D. A.; Wesolowski, D. J. Dissociation Quotients for Citric Acid In Aqueous Sodium Chloride Media to $150{ }^{\circ} \mathrm{C}$. J. Solution Chem. 1997, 26 (1), 63-84. DOI: 10.1007/ BF02439444.

44. Fukada, H.; Takahashi, K. Enthalpy and Heat Capacity Changes for the Proton Dissociation of Various Buffer Components in $0.1 \mathrm{M}$ Potassium Chloride. PROTEINS: Struct., Funct. Genet. 1998, 33 (2), 159-166. DOI:10.1002/(SICI)10970134(19981101)33:2<159::AID-PROT2>3.0.CO;2-E.

45. Bower, V. E.; Bates, R. G. pH Values of the Clark and Lubs Buffer Solutions at $25^{\circ} \mathrm{C}$. J. Res. Natl. Bur. Stand. (U.S.) 1955, 55 (4), 197-200.

46. Kennedy, C. D. Ionic Strength and the Dissociation of Acids. Biochem. Educ. 1990, 18 (1), 35-40.

47. Partanen, J. I.; Kärki, M. H. Determination of the Thermodynamic Dissociation Constant of a Weak Acid by Potentiometric AcidBase Titration. J. Chem. Educ. 1994, 71 (5), A120-A122.

48. Xu, X; Khan, M. K.; Burgess, D. J. A Two-Stage Reverse Dialysis In Vitro Dissolution Testing Method for Passive Targeted Liposomes. Int. J. Pharm. 2012, 426, 211-218. DOI: 10.1016/j. ijpharm.2012.01.030.

49. Avdeef, A.; Tsinman, O. Miniaturized Rotating Disk Intrinsic Dissolution Rate Measurement: Effects of Buffer Capacity in Comparisons to Traditional Wood's Apparatus. Pharm. Res. 2008, 25 (11), 2613-2627. DOI: 10.1007/s11095-008-9679-z.

50. Van Slyke, D. D. On the Measurement of Buffer Values and on the 
Relationship of Buffer Value to the Dissociation Constant of the Buffer and the Concentration and Reaction of the Buffer Solution. J. Biol. Chem. 1922, 52 (2), 525-570.

51. Chuy, S.; Bell, L. N. Buffer $\mathrm{pH}$ and $\mathrm{pKa}$ Values as Affected by Added Glycerol and Sucrose. Food Res. Int. 2006, 39, 342-348. DOI: 10.1016/j.foodres.2005.08.006.

52. Bates, R. G. Determination of $\mathrm{pH}$. Theory and Practice, 2nd ed.; John Wiley and Sons: New York, 1973; pp 115-122.

53. Stippler, E.; Kopp, S.; Dressman, J. B. Comparison of US Pharmacopeia Simulated Intestinal Fluid TS (Without Pancreatin) and Phosphate Standard Buffer pH 6.8, TS of the International Pharmacopeia with Respect to Their Use in In Vitro Dissolution Testing. Dissolution Technol. 2004, 11 (2), 6-10. DOI: 10.14227/ DT110204P6.

54. Ramtoola, Z.; Corrigan, O. I. Influence of the Buffering Capacity of the Medium on the Dissolution of Drug-Excipient Mixtures. Drug Dev. and Ind. Pharm. 1989, 15, 2359-2374. DOI: 10.3109/03639048909052535.

55. Govindarajan, R.; Landis, M.; Hancock, B.; Gatlin, L. A.; Suryanarayanan, R.; Shalaev, E. Y. Surface Acidity and Solid-State Compatibility of Excipients with an Acid-Sensitive API: Case Study of Atorvastatin Calcium. AAPS PharmSciTech. 2015, 16 (2), 354363. DOI: 10.1028/s12249-014-0231-7.

56. Garbacz, G.; Kolodziej, B.; Koziolek, M.; Weitschies, W.; Klein, S. An Automated System for Monitoring and Regulating the $\mathrm{pH}$ of Bicarbonate Buffers. AAPS PharmSciTech. 2013, 14 (2), 517-522. DOI: 10.1208/s12249-013-9933-5.

57. Macca, C.; Solda, L. pH-Static Techniques in Volumetric Analysis II. Experimental Study of $\mathrm{pH}$-Static Acid-Base Titrations. Electroanalysis. 2002, 14 (1), 63-70. DOI: 10.1002/15214109(200201)14:13.0.CO;2-1.

58. Beynon, R. J.; Easterby, J. S. Buffer Solutions - The Basics; IRL PRESS at Oxford University Press: Oxford, 1996.

59. Hamed, R.; Awadallah, A.; Sunoqrot, S.; Tarawneh,O.; Nazzal, S.; AlBaraghthi, T.; Al Sayyad, J.; Abbas, A. pH-Dependent Solubility and Dissolution Behavior of Carvedilol - Case Example of a Weakly Basic BCS Class II Drug. AAPS PharmSciTech. 2016, 17 (2), 418-426. DOI: 10.1208/s12249-015-0365-2.

60. Edsall, J. T.; Wyman, J. Biophysical Chemistry, Vol. 1; Academic Press Inc: New York, 1958; p 422.

61. Stellwagen, E.; Prantner, J. D.; Stellwagen, N. C. Do Zwitterions Contribute to the lonic Strength of a Solution? Anal. Biochem. 2008, 373, 407-409. DOI: 10.1016/j.ab.2007.10.038.

62. Svensson, H. Isoelectric Fractionation, Analysis, and Characterization of Ampholytes in Natural pH Gradients. II. Buffering Capacity and Conductance of Isoionic Ampholytes. Acta Chem. Scand. 1962, 16, 456-466.

63. Lalwani, S.; Tutu, E.; Vigh, G. Isoelectric Buffers, Part 3: Determination of pKa and PI Values of Diamino Sulfate Carrier Ampholytes By Indirect UV-Detection Capillary Electrophoresis.
Electrophoresis. 2005, 26, 2503-2510. DOI: 10.1002/ elps.200500002.

64. Butler, J. N. Ionic Equilibrium-AMathematicalApproach; AddisonWesley Publishing Company, Inc.: Reading, Massachusetts, 1964; p 433.

65. Malmberg, C. G.; Maryott, A. A. Dielectric Constant of Water from $0^{\circ}$ to $100^{\circ} \mathrm{C}$, J. Res. Natl. Bur. Stand. (U.S.). 1956, 56 (1), 1-8.

66. Staples, B. R.; Bates, R. G. Two New Standards for the pH Scale, J. Res. Natl. Bur. Stand. (U.S.) - A. Physics and Chemistry. 1969, 73A (1), 37-41.

67. Wu, Y.; Levons, J.; Narang, A. S.; Raghavan, K.; Rao, V. M. Reactive Impurities in Excipients: Profiling, Identification and Mitigation of Drug-Excipient Incompatibility. AAPS PharmSciTech. 2011, 12 (4), 1248-1263. DOI: 10.1028/s12249-011-9677-z.

68. Fisher, B. E.; Haring, U. K.; Tribolet, R.; Sigel, H. Metal Ion/ Buffer Interactions. Stability of Binary and Ternary Complexes Containing 2-Amino -2(hydroxymethyl)-1,3-propanediol (Tris) and Adenosine 5'-Triphosphate (ATP). Eur. J. Biochem. 1979, 94, 523-530.

69. Taha, M.; Gupta, B. S.; Khoiroh, I;; Lee, M. J. Interactions of Biological Buffers: The Ubiquitous "Smart" Polymer PNIPAM and the Biological Buffers, MES, MOPS and MOPSO. Macromolecules. 2011, 44, 8575-8589. DOI:10.1021/ma201790c.

70. Greenwald, I. The Dissociation of Some Calcium Salts. J. Biol. Chem. 1938, 124, 437-452.

71. Ment, W. M.; Naviasky, H. S. Effect Of Maleic Acid in Compendial UV Absorption Assays for Antihistamine Maleate Salts. J. Pharm. Sci. 1974, 63 (10), 1604-1609. DOI: 10.1002/jps.2600631024.

72. Singh, A.; Sharma, P. K.; Majumbar, D. K. Development and Validation of New HPLC-Methods for Estimation of Fluconazole in Different Simulated Biological Fluids: A Comparative Study. J. Liq. Chromatog. Relat. Technol. 2014, 37 (4), 594-607. DOI: 10.1080/10826076.2012.758131.

73. Serajuddin, A. T. M. Salt Formation to Improve Drug Solubility. Adv. Drug Delivery Rev. 2007, 59, 603-616. DOI: 10.1016/j. addr.2007.05.010.

74. Higuchi, T.; Shih, F. M. L.; Kimura, T.; Rytting, J. H. Solubility Determination of Barely Aqueous-Soluble Organic Solids. J. Pharm. Sci. 1979, 68 (10), 1267-1272.

75. Dressman, J. B.; Vertzoni, M.; Goumas, K.; Reppas, C., Estimating Drug Solubility in the Gastrointestinal Tract. Adv. Drug Delivery Rev. 2007, 59, 591-602. DOI: 10.1016/j.addr.2007.05.009.

76. Persat, A.; Chambers, R. D.; Santiago, J. G. Basic Principles of Electrolyte Chemistry for Microfluidic Electrokinetics. Part I: AcidBase Equilibria and pH Buffers. Lab Chip. 2009, 9, 2437-2453. DOI: 10.1039/b906465f.

77. Berge, S. M.; Bighley, L. D.; Monkhouse, D. C. Pharmaceutical Salts. J. Pharm. Sci. 1977, 66 (1), 1-19.

78. Handbook of Pharmaceutical Salts: Properties, Selection and Use; Stahl, P. H.; Wermuth, C. G., Eds.; Wiley-VCH: Weinheim, 2008. 
79. Farheen, H.; Mamatha, T.; Yasmeen, Z.; Sutradhar, S. Dissolution Method Development and Validation of Paracetamol Aceclofenac Tablets. Int. J. Pharm. Chem. Sci. 2013, 2 (2), 902-908.

80. Mooney, K. G.; Mintun, M. A.; Himmelstein, K. J.; Stella, V. J. Dissolution Kinetics of Carboxylic Acids II: Effect of Buffers. J. Pharm. Sci. 1981, 70 (1), 22-32.

81. Pfannkoch, E.A. The Preparation of Buffers and Other Solutions:
A Chemist's Perspective, In Molecular Biology Problem Solver: A Laboratory Guide; Gerstein, A. S., Ed.; John Wiley \& Sons: New York, 2001. DOI: 10.1002/0471223905.ch3.

82. Prankerd, R. J. Critical Compilation of pKa Values for Pharmaceutical Substances. In Profiles of Drug Substances, Excipients, and Related Methodology; Brittain, H. G., Ed.; Academic Press: Boston, 2007; Vol. 33, p 2. 